\title{
Superior Pancreatico-Duodenal Artery
}

National Cancer Institute

\section{Source}

National Cancer Institute. Superior Pancreatico-Duodenal Artery. NCI Thesaurus. Code C52742.

An artery arising from the gastroduodenal artery that supplies the common bile duct, duodenum, and the head of the pancreas. 